\title{
Feasibility of Solar-Enhanced Drying of Woody Biomass
}

\author{
Jyrki Raitila ${ }^{1}$ (D) Eemeli Tsupari ${ }^{1}$
}

Published online: 10 November 2019

(C) The Author(s) 2019

\begin{abstract}
Sustainable biomass resources are limited and their utilization therefore needs to be more efficient. In addition, there is an urgent need for low-cost energy storage, particularly for solar energy. Drying considerably increases the calorific value of woody biomass, and the resulting dried biomass provides easy seasonal energy storage. The drying both improves the quality of the biomass and extends its storage life. To investigate the technology and feasibility of solar-enhanced drying, several drying experiments were conducted on wood chips in VTT's $12 \mathrm{~kW}_{\text {peak }}$ convective dryer in Jyväskylä, Finland. Drying times varied from 3.5 to $27 \mathrm{~h}$ and the final moistures from 12 to $32 \mathrm{w}-\%$. VTT's experiments show that solar heat can be successfully applied to thermal drying of biomass. The moderate drying temperatures used (typically $20-50{ }^{\circ} \mathrm{C}$ ) are advantageous for ensuring homogenous drying of wood particles and for preventing changes to the physical structure of the biomass and loss of volatiles. Due to the low efficiency of the system, still in its prototype phase, the calculated payback times were not highly attractive to the entrepreneur. In the experiments, best profitability was achieved by drying seasoned wood, for which a payback time of 1217 years was estimated for a large scale system such as a biomass terminal. Based on the assumptions that technical improvements are made, the best drying efficiency reached in our experiments is achieved, and some investment subsidy is secured; scale-up is feasible. With these criteria met, the payback time of such a dryer could be brought below 10 years. This requires, however, that drying increases the selling price of wood chips.
\end{abstract}

Keywords Wood chips $\cdot$ Biomass drying $\cdot$ Solar energy $\cdot$ Bioenergy $\cdot$ Energy storage

\section{Introduction}

Climate change mitigation calls for urgent measures to substitute fossil fuels and materials with renewable solutions. In this, biomass is playing an increasing role [1]. However, sustainable biomass resources are limited, especially regionally. In addition, the carbon neutrality of different biomass fractions has been questioned [2]. The calorific value of sustainable woody biomass resources can be significantly increased through drying [3-5]. On the other hand, there is an urgent need for low-cost energy storage applications, especially with regard to solar energy [6]. The technical potential to utilize solar energy in Europe and even in northerly-situated Finland is several times greater than current energy consumption in these regions $[7,8]$. The main technical challenges relate to

Jyrki Raitila

jyrki.raitila@vtt.fi

1 VTT Technical Research Centre of Finland, PO Box 1603, FI-40101 Jyväskylä, Finland the intermittency of available solar energy, such as day-night and summer-winter cycles [9]. Decentralized biomass drying located near to the raw material source reduces transportation costs and enables distributed energy storage networks [10]. Furthermore, the overall efficiency of energy production increases and emissions decrease [11].

Newly harvested logging residues and small diameter fuel wood have a moisture content of over $50 \mathrm{w}-\%$ [12]. Moisture content is an important quality parameter, because it reduces the calorific value of fuel. For example, with moisture content of $50 \%$, the effective calorific value is $16 \mathrm{MJ} / \mathrm{kg}$ compared with $19 \mathrm{MJ} / \mathrm{kg}$ for dry fuel [13]. Forest fuel raw materials are usually stored and seasoned at the landing near the logging site before comminution and transportation to an energy plant $[14,15]$. The storage time varies from a few months to over a year. In natural drying, understandably, ambient conditions play a very important role in the drying process. During this time, a significant amount of capital is tied up in the feedstock. At the same time, there is high risk that the quality of the wood will not improve as desired.

Biomass dried with solar energy could serve as a means of seasonal energy storage, diminishing risks in biomass fuel delivery and ensuring smooth power plant operation [16]. 
Wood fuel supply operates year round, but in Nordic regions, the demand is much higher from October to March [17], thus requiring buffer storages for high seasons. Dryer biomass is much easier to store and it renders more energy for the same volume of wood. The quantity of biomass available for energy and for biorefinery products is ultimately affected by the dry matter loss that inevitably occurs during storage [18]. Conditions conducive to extensive biodegradation include a temperature of $15-60{ }^{\circ} \mathrm{C}$, moisture level above fiber saturation point (usually above $25 \mathrm{w}-\%$ ), and favorable oxygen and carbon dioxide concentrations [19]. Drying significantly decreases microbial activity in woody biomass, thus improving handling conditions and preventing dry matter loss [20]. Low moisture $<10$ to $15 \mathrm{w}-\%$ also ensures a high feedstock quality for new bio-products.

The BEST project (Sustainable Bioenergy Solutions for Tomorrow) studied a so-called "fast track" solution for supplying woody biomass to power plants. In that model, the storage time was limited to effective outdoor drying months in spring and early summer. The fast track calculations with $8 \%$ interest rate showed that supply costs can be decreased by 8 to $13 \%$ depending on the dry matter loss level [21]. In this model, however, the benefits were limited by the time of the natural drying season. If solar energy could be stored in wood fuel feedstocks through enhanced drying, significant savings in wood consumption could be reached. For example, if the moisture content of $40 \mathrm{w}-\%$, typically reached in natural drying in Northern Europe, can be reduced to $20 \mathrm{w}-\%, 14 \%$ more energy can be generated with the same amount of wood [22].

Compared to natural seasoning, warm air-drying, for example in a convective dryer, provides several benefits. Warm air-drying is usually more effective, can be better controlled, and the desired quality and storability can be ensured. If solar collectors are used to enhance the drying process, the viability of such a system is still limited by ambient conditions, but not as much as pure seasoning. Solar collectors can extend the effective drying season to more than 6 months in Northern Europe [23]. In addition, recent developments in the efficiency and cost of solar systems make solar drying more feasible in different applications.

Studies on the supply systems of wood fuel based on artificial drying have not been published recently [22]. However, solar enhanced drying has been used in different small-scale applications in agriculture and fishery. Product quality depends on many factors, including drying temperature and duration. Low temperatures are favored when important volatile compounds need to be preserved in the biomaterial. This corresponds well with drying wood. Various solar drying systems (SDS) designs for agricultural products have been reviewed in Asia [24-26], such as chamber-type (rack-type/ tray-, bin-, and tunnel-type) and chimney-type SDS. These designs are all recommended for commercial use. The main components of the system are solar collectors, a blower, a drying chamber, and sometimes an auxiliary electric heater. According to the study of Fudholi et al. [27], temperatures of 50 to $55^{\circ} \mathrm{C}$ could be reached at a solar radiation level of $650 \mathrm{~W} / \mathrm{m}^{2}$. On the other hand, system efficiency levels were quite low, only 20 to $30 \%$. Solar drying systems saved drying time 35 to $76 \%$ compared to natural seasoning.

In a bit older study, Sharma et al. [28] identify two broad groups of solar-energy dryers, passive or natural-circulation solar-energy dryers and active or forced-convection solar-energy dryers. The latter ones are more applicable here. According to this review, as high as $60{ }^{\circ} \mathrm{C} \pm 3{ }^{\circ} \mathrm{C}$ were reached. System efficiencies varied between 0.3 and 0.8 during drying experiments and that the higher flow rates increase the overall drying performance and especially efficiency.

Based on the above presented introduction, there is an increasing global demand for limited sustainable bioenergy resources, which could be used more effectively utilizing solar enhanced drying. However, there is only fragmented information available about the economic feasibility of solar enhanced drying of bioenergy. Objectives with regard to our solar drying studies included building a dryer prototype, configuring different drying modes for profitable operation of the test facility, and evaluating the efficiency and profitability of solar-enhanced drying in scaled-up solutions. Objectives also included experimenting drying in a solar enhanced dryer and evaluating its suitability for wood fuel drying.

\section{Methodology}

\section{Design and Operation Principle of the Drying System}

The drying system at VTT comprises six flat-plate solar heatcollecting modules with a total collector surface area of $12 \mathrm{~m}^{2}$ and corresponding to roughly $10 \mathrm{~kW}_{\text {peak }}$, with heat transfer liquid, heat exchanger, and air ducting for supply of heated air to the biomass drying equipment. The solar modules, manufactured by Savosolar, are positioned on the flat roof and have been installed to maximize solar energy use throughout the day, not only at peak hours. Therefore, instead of facing them directly south, half were directed southwest $\left(103^{\circ}\right.$ from north) and the other half southeast $\left(185^{\circ}\right.$ from north) with a $54^{\circ}$ inclination. In August of the same year (2017), the inclination was changed according to general recommendations to $43^{\circ}$ and the orientations to precisely $140^{\circ}$ and $220^{\circ}$. These changes, however, seem to have had little impact on the amount of solar energy collected. A far more important factor was weather conditions.

The biomass drying equipment is installed inside the building and includes a convective drying chamber with separate trays for loading the material and the necessary measurement and control devices for testing purposes. For drying 
experiments, $1 \times 1 \times 0.3 \mathrm{~m}$ or $1 \times 1 \times 0.8 \mathrm{~m}$ trays corresponding to volumes of $0.3 \mathrm{~m}^{3}$ or $0.8 \mathrm{~m}^{3}$ can be used. The device is modular and can be deployed easily.

The solar system is controlled with a Resol DeltaSol MX control unit commonly used in household solar heating and ventilation systems. Control can be based on difference in temperature or flow, or a timer. In our experiments, the difference in temperature of the glycol-water fluid in the heat transfer pipes was the main controller of the solar collector system. The pump unit controlled by Resol is equipped with two circulating pumps (one for each group of solar collectors), stop valves, safety valves, and pressure and temperature meters. Heat is transferred with the glycol-water fluid to a heat exchanger (Ecocoil). Airflow for drying is produced with a System Air $308 \mathrm{~W}$ duct fan. The system is illustrated in Figs. 1, 2, and 3.

\section{Experiments and Measurement Procedure}

First, algorithms to control the airflow to the dryer were developed to optimize the drying process in varying conditions with regard to solar irradiation, drying air temperature, air humidity, and electricity price. The algorithms were created to either (1) maximize the economic benefits of drying (benefits-costs), (2) maximize drying intensity (maximum difference of concentration of water between the exhaust air and ambient air), or (3) to observe the

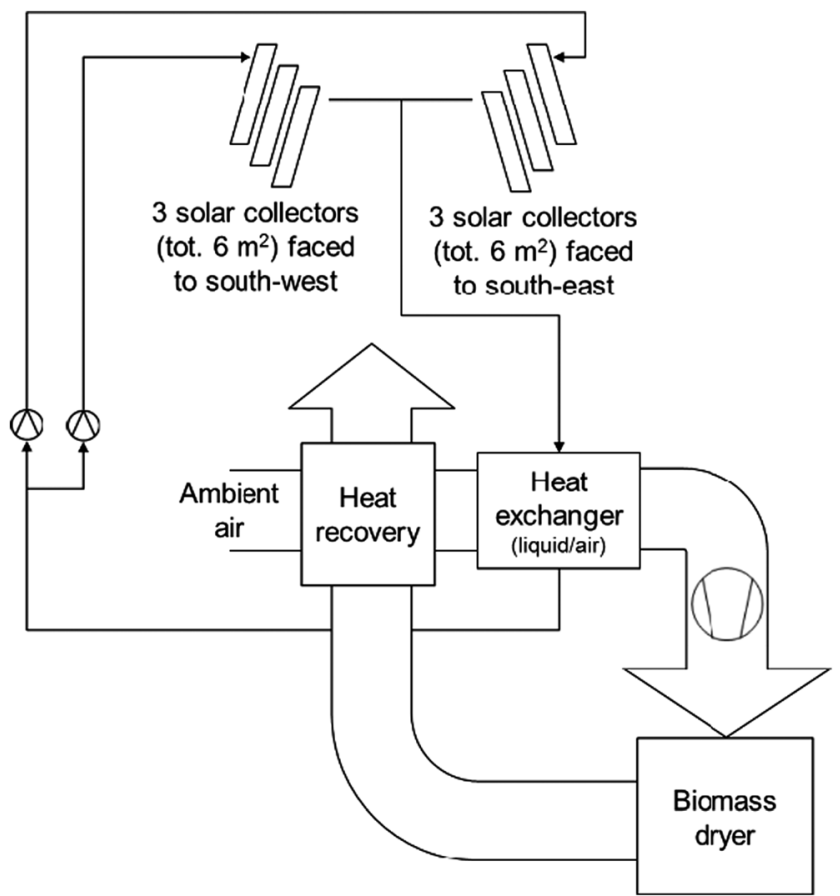

Fig. 1 The flowsheet of the used solar enhanced drying system. Some variations and improvements to the system were made during the study as presented in the text ("Experiments and Measurement Procedure" section) airflow levels at which drying is economic, and, in unfavorable conditions, to switch the fan to minimum flow. The principles of the used algorithms are illustrated in Appendix A. Solar-enhanced drying experiments were conducted mainly in August 2017, June 2018, and August 2018, and a few in the first week of September and late May at VTT in Jyväskylä. Initially, all three algorithms were used systematically [29]. Once we had verified that all of the algorithms work and that algorithm 1 (maximizing economic benefits) rendered the best results, most experiments, particularly in 2018, were conducted with this algorithm. The possible effects of the different algorithms were not analyzed because conditions varied between experiments with regard to the weather and duration.

In April 2018, a heat recovery unit was installed on the exhaust air stream. In addition, in August 2018, the position of the solar collectors was slightly adjusted. In the last experiments (experiments 19-22 in August 2018, only half of the collectors were used and these were re-positioned to face directly south.

About 0.3 loose $\mathrm{m}^{3}$ of wood was dried in most experiments. This corresponded to about $60 \mathrm{~kg}$ of fresh wood chips and $50 \mathrm{~kg}$ of semi-dry chips. In comparison, bigger batches of $181 \mathrm{~kg}$ (fresh) and 97-143 kg (semi-dry) chips were also dried. The goal was to dry the wood chips to a moisture content of between 20 and $30 \mathrm{w}-\%$. Wood chips must be dried to this target moisture level, or lower, to prevent loss of quality and dry matter through biodegradation [19].

In the drying experiments, two types of wood were used: fresh wood chips and seasoned wood chips, in size classes P16 and F15 [30]. All wood chips were manufactured from small-diameter (7-15 $\mathrm{cm}_{\mathrm{bh}}$ ) pine logs (Table 1). The logs were chipped with an agricultural tractor-powered disc chipper. Half of the logs was seasoned at the roadside for 3 months to pre-dry before comminution, and the other half was chipped directly after harvesting.

In practice, the drying times and the attained moisture levels varied due to batch size but also different ambient conditions, solar irradiation being the most critical factor. Drying air was blown through the biomass batch from top to bottom. Drying times varied from 3.5 to $27 \mathrm{~h}$. The final moistures varied from 12 to $32 \mathrm{w}-\%$. Changing drying conditions served the purpose of the experiments well as one of the main points of interest was to compare drying results in different conditions. The main characteristics of the experiments analyzed in this paper are summarized in Table 1.

Each drying batch was weighed before and after drying to determine the amount of evaporated water. The following variables were measured via continuous data collection from the process: electric current of the fan (A), air flow $\left(\mathrm{Nm}^{3} / \mathrm{h}\right)$, relative humidity of incoming and exhaust air $(\% \mathrm{RH})$, pressure of incoming and exhaust air (mbar), temperature of 
Fig. 2 VTT's solar heat collectors

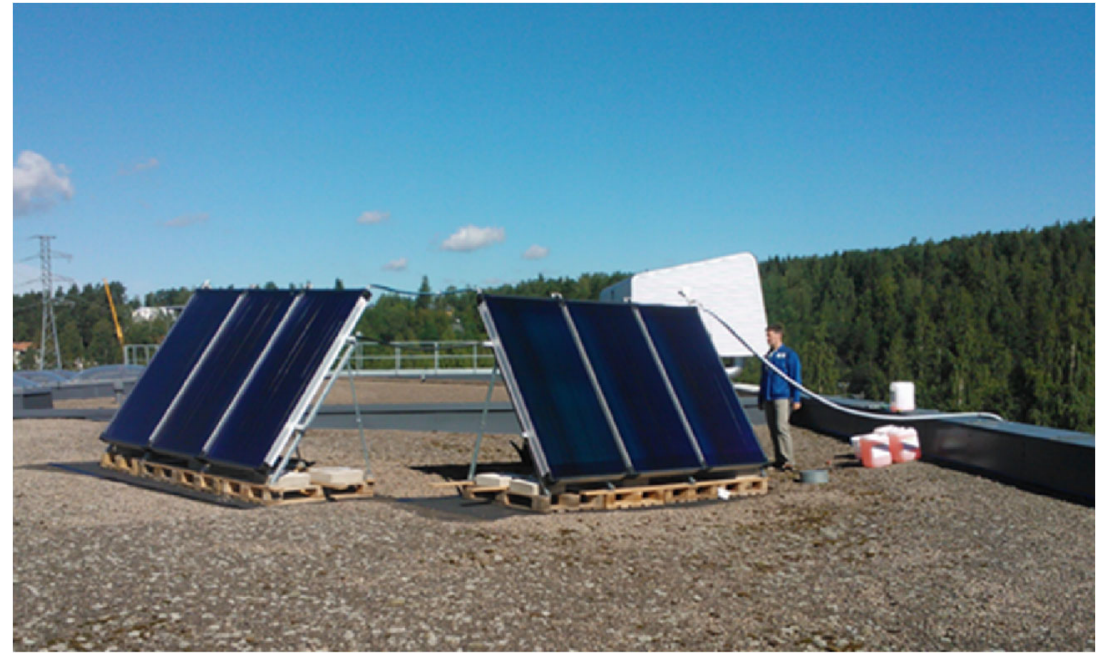

incoming and exhaust air $\left({ }^{\circ} \mathrm{C}\right)$, temperature of air after solar heat exchanger $\left({ }^{\circ} \mathrm{C}\right)$, temperatures at several points of solar heat circulation $\left({ }^{\circ} \mathrm{C}\right)$, liquid flow in solar circulation (liters/h), and irradiation on a horizontal surface $\left(\mathrm{W} / \mathrm{m}^{2}\right)$. In addition to operation algorithms (as presented in Appendix A), these measurements contributed to the online moisture monitoring, helping to reach the targeted moisture level after drying.

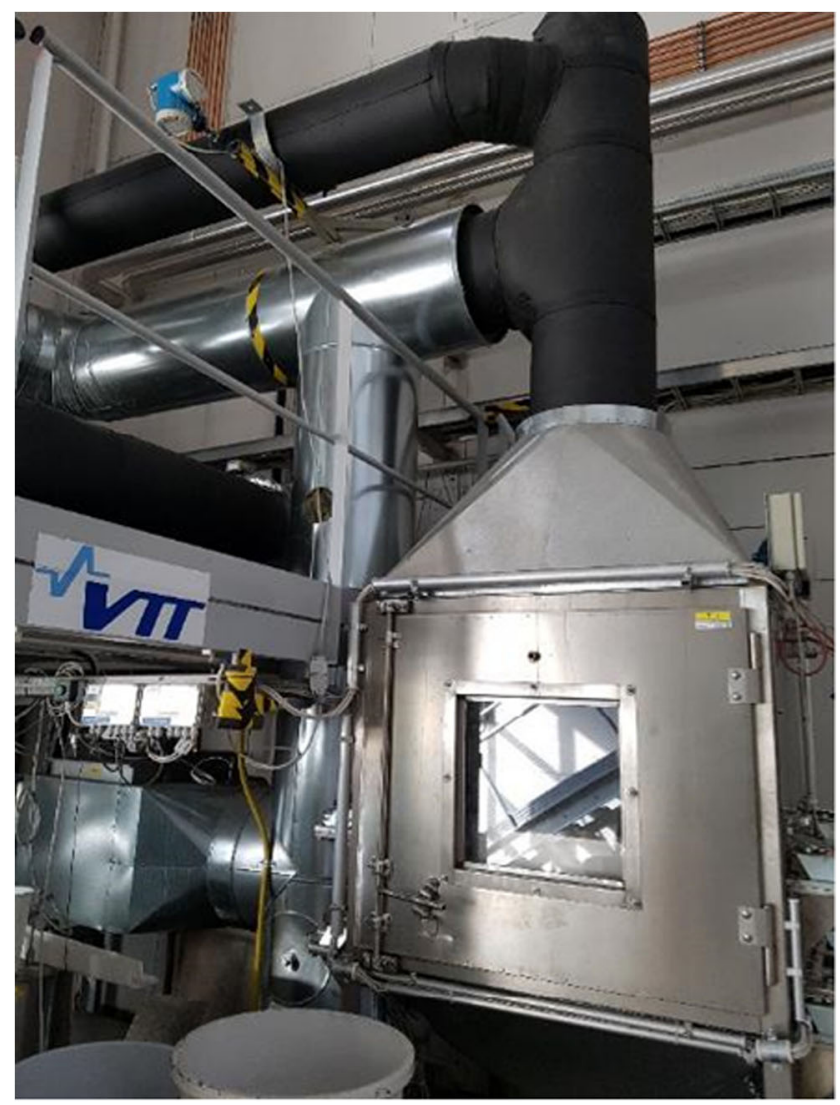

Fig. 3 VTT's biomass dryer

\section{Calculation Principles}

Biomass price was assumed at $€ 21 / \mathrm{MWh}$ before drying and $€ 25 / \mathrm{MWh}$ after drying, based on common average wood fuel prices in Finland [31]. It was assumed that dried biomass is more valuable either sold or used in an own boiler due to improved quality, better storability, and lower transportation costs. Based on these costs and the measured properties of studied materials, the economic benefit of drying per evaporated water, BoD ( $\left.€ / \mathrm{MWh}_{\text {evaporation }}\right)$ was calculated by Equation 1.

$\mathrm{BoD}=\frac{\text { BioPriceDry } \times \text { MWhdry }- \text { BioPriceWet } \times \text { MWhwet }}{\text { MWhdry }- \text { MWhwet }}$

where

BioPriceDry $=$ Biomass price before drying $(€ / M W h)$

MWhdry $=$ Lower heating value of biomass after drying per dry solids (MWh/kg dry solids)

BioPriceWet $=$ Biomass price after drying $(€ / \mathrm{MWh})$

MWhwet $=$ Lower heating value of biomass before drying per dry solids (MWh/kg dry solids)

The variable cost of electricity was $€ 110 / \mathrm{MWh}$ in the calculations and adjusting algorithms. The additional labor costs due to drying were estimated to be insignificant in comparison to a traditional biomass supply chain and were therefore not included in the calculation. With these assumptions and measurements, the following calculations were made: heat consumed for evaporation ( $\mathrm{kW}$ ), mass flow of evaporated water $(\mathrm{kg} / \mathrm{s})$, cumulative amount of evaporated water $(\mathrm{kg})$, absolute moisture of the air before and after the dryer $\left(\mathrm{g} / \mathrm{Nm}^{3}\right)$, power consumption $(\mathrm{kWh})$, and heat transfer to drying air $(\mathrm{kW})$. 
Table 1 Summary of the drying experiments ( $i$ inclination of solar collectors)

\begin{tabular}{|c|c|c|c|c|c|c|}
\hline $\begin{array}{l}\text { Experiment } \\
\text { no. }\end{array}$ & $\begin{array}{l}\text { Wood } \\
\text { type }\end{array}$ & $\begin{array}{l}\text { Initial } \\
\text { moisture, w- } \\
\%\end{array}$ & $\begin{array}{l}\text { Final } \\
\text { moisture, w- } \\
\%\end{array}$ & $\begin{array}{l}\text { Batch } \\
\text { weight, } \mathrm{kg}\end{array}$ & $\begin{array}{l}\text { Solar collector } \\
\text { positioning }\end{array}$ & $\begin{array}{l}\text { Heat } \\
\text { recovery, } \\
\mathrm{Y} / \mathrm{N}\end{array}$ \\
\hline 1 & Fresh & 54.5 & 31.6 & 66.3 & $103^{\circ}, 185^{\circ}, 54^{\circ} \mathrm{i}$ & $\mathrm{N}$ \\
\hline 2 & Fresh & 54.5 & 30.2 & 62.7 & $103^{\circ}, 185^{\circ}, 54^{\circ} \mathrm{i}$ & $\mathrm{N}$ \\
\hline 3 & Fresh & 54.5 & 31.9 & 60.4 & $103^{\circ}, 185^{\circ}, 54^{\circ} \mathrm{i}$ & $\mathrm{N}$ \\
\hline 4 & Fresh & 54.5 & 30.6 & 60.6 & $140^{\circ}, 220^{\circ}, 43^{\circ} \mathrm{i}$ & $\mathrm{N}$ \\
\hline 5 & Fresh & 54.5 & 23.9 & 60.1 & $140^{\circ}, 220^{\circ}, 43^{\circ} \mathrm{i}$ & $\mathrm{N}$ \\
\hline 6 & Fresh & 54.5 & 24.4 & 62.3 & $140^{\circ}, 220^{\circ}, 43^{\circ} \mathrm{i}$ & $\mathrm{N}$ \\
\hline 7 & Fresh & 54.5 & 23.9 & 65.4 & $140^{\circ}, 220^{\circ}, 43^{\circ} \mathrm{i}$ & $\mathrm{Y}$ \\
\hline 8 & Fresh & 55.4 & 27.2 & 62.2 & $140^{\circ}, 220^{\circ}, 43^{\circ} \mathrm{i}$ & $\mathrm{Y}$ \\
\hline 9 & Fresh & 55.5 & 17.2 & 62.2 & $140^{\circ}, 220^{\circ}, 43^{\circ} \mathrm{i}$ & $\mathrm{Y}$ \\
\hline 10 & Fresh & 55.4 & 40.8 & 181.4 & $140^{\circ}, 220^{\circ}, 43^{\circ} \mathrm{i}$ & $\mathrm{Y}$ \\
\hline 11 & Seasoned & 42.0 & 28.6 & 52.6 & $103^{\circ}, 185^{\circ}, 54^{\circ} \mathrm{i}$ & $\mathrm{N}$ \\
\hline 12 & Seasoned & 42.0 & 18.3 & 51.9 & $103^{\circ}, 185^{\circ}, 54^{\circ} \mathrm{i}$ & $\mathrm{N}$ \\
\hline 13 & Seasoned & 42.0 & 16.0 & 52.5 & $103^{\circ}, 185^{\circ}, 54^{\circ} \mathrm{i}$ & $\mathrm{N}$ \\
\hline 14 & Seasoned & 42.0 & 27.6 & 53.9 & $140^{\circ}, 220^{\circ}, 43^{\circ} \mathrm{i}$ & $\mathrm{N}$ \\
\hline 15 & Seasoned & 46.0 & 18.5 & 139.4 & $140^{\circ}, 220^{\circ}, 43^{\circ} \mathrm{i}$ & $\mathrm{Y}$ \\
\hline 16 & Seasoned & 46.0 & 19.3 & 50.7 & $140^{\circ}, 220^{\circ}, 43^{\circ} \mathrm{i}$ & $\mathrm{Y}$ \\
\hline 17 & Seasoned & 44.0 & 16.9 & 44.0 & $140^{\circ}, 220^{\circ}, 43^{\circ} \mathrm{i}$ & $\mathrm{Y}$ \\
\hline 18 & Seasoned & 48.0 & 13.8 & 143.4 & $140^{\circ}, 220^{\circ}, 43^{\circ} \mathrm{i}$ & $\mathrm{Y}$ \\
\hline 19 & Seasoned & 38.7 & 20.0 & 42.1 & $180^{\circ}, 43^{\circ} \mathrm{i}$ & $\mathrm{Y}$ \\
\hline 20 & Seasoned & 38.7 & 21.5 & 106.9 & $180^{\circ}, 43^{\circ} \mathrm{i}$ & $\mathrm{Y}$ \\
\hline 21 & Seasoned & 38.7 & 16.3 & 44.9 & $180^{\circ}, 43^{\circ} \mathrm{i}$ & $\mathrm{Y}$ \\
\hline 22 & Seasoned & 38.7 & 25.4 & 96.9 & $180^{\circ}, 43^{\circ} \mathrm{i}$ & $\mathrm{Y}$ \\
\hline
\end{tabular}

The profitability (gross margin, EBIT DA) of the drying experiments was calculated by Equation 2 .

$\operatorname{EBIT} \mathrm{DA}(€ / \mathrm{h})=\operatorname{Benefit}(€ / \mathrm{h})-\operatorname{Costs}(€ / \mathrm{h})$

where

$$
\begin{aligned}
\text { Benefit }= & \operatorname{BoD}(€ / \mathrm{MWh}) \\
& \times \text { mass flow of evaporated water }(\mathrm{kg} / \mathrm{s}) \\
& \times 2.258(\mathrm{MJ} / \mathrm{kg})
\end{aligned}
$$

Costs $=$ electricity consumption $(\mathrm{kWh} / \mathrm{h}) / 1000$

$$
\times \text { cost of electricity }(€ / \mathrm{MWh})
$$

Data from the continuous online measurements was used with the previous equations by the algorithms during the operation. Because combination of online measurements is not that accurate than a scale, EBIT DA was recalculated after the drying experiments using previous equations with Eq. 3, based on a weight difference of the batches before and after drying as a total amount of evaporated water during the experiment.

$$
\begin{gathered}
\operatorname{Benefit}(€ / \text { batch })=\operatorname{BoD}(€ / \mathrm{MWh}) * \text { evaporation }(\mathrm{kg} / \mathrm{batch}) \\
* 2.258(\mathrm{MJ} / \mathrm{kg}) / 3.6(\mathrm{MWh} / \mathrm{MJ})
\end{gathered}
$$

EBIT DA of each test is presented in Fig. 1 as a function of solar irradiation on a horizontal surface during the tests. In order to estimate the feasibility of full-scale systems, the results presented in Fig. 1 were extrapolated in time and scaled up for a larger capacity.

\section{Extrapolation in Time}

As Fig. 4 shows, the correlation between profitability and irradiation seems almost linear even when the conditions during the experiments varied. Therefore, the profitability of annual operation was assessed by extrapolating the linear trend line fitted to experiment results for cumulative irradiation on a horizontal surface during the drying season on an average year. The irradiation is dependent on the location and can be 
Fig. 4 Profitability of drying as a function of measured irradiation on horizontal surface during the experiments

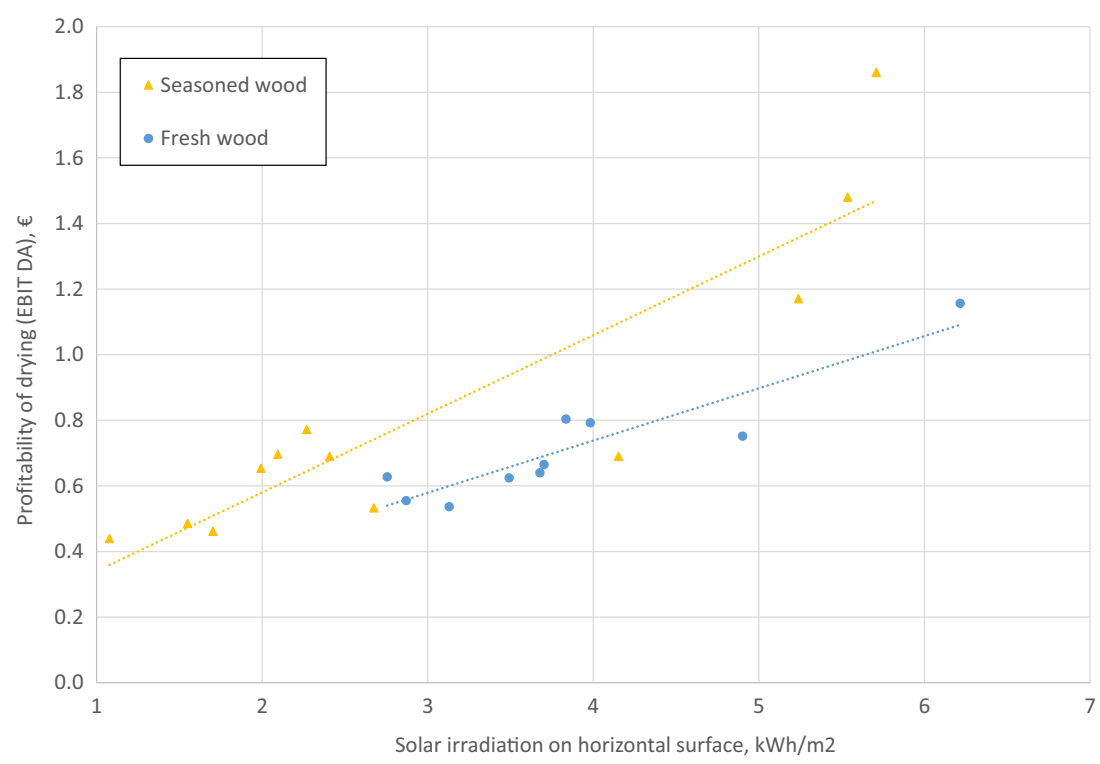

estimated using the PVGIS tool, made available by the Joint Research Centre of EU [23]. In our study, the irradiation levels for Jyväskylä, Central Finland were used. The drying season was estimated to be from the beginning of March to the end of September, resulting in an annual irradiation of $807 \mathrm{kWh} / \mathrm{m}^{2}$ on horizontal surface [23].

\section{Scale-up and Investment Costs}

The calculations were scaled up to a larger drying system equipped with either $90 \mathrm{~m}^{2}$ (farm dryer) or 5,000 $\mathrm{m}^{2}$ (biomass terminal) solar collectors. This was done by estimating the constant dryer capacity per solar system surface area. The annual gross margin was consequently also multiplied by the ratio of solar collector surface areas, $90 \mathrm{~m}^{2} / 12 \mathrm{~m}^{2}$ and $5,000 \mathrm{~m}^{2} / 12 \mathrm{~m}^{2}$ respectively. In those experiments where only half of the collectors were applied, the results were multiplied by $90 / 6$ and $5000 / 6$.

Investment costs were based on the assumption that the smaller dryer is built inside an existing building, such as a barn, with retrofit costs including, for example, investment in fans, timberwork, and new floor casting to ensure effective drying air distribution. The investment costs of the bigger dryer included, however, a new building as well as a storage facility for the dried biomass, as it cannot be assumed that buildings of this size are available without significant cost. All costs were estimated based on ProAgria's [32] general construction plans. It should be noted that the most important cost is the solar collector system, for which price estimates were received from Savosolar Ltd., a Finnish supplier of solar collector systems. In total, the used default investments were $€ 63,000$ and roughly $€ 2.4$ million for the $90 \mathrm{~m}^{2}$ and $5,000 \mathrm{~m}^{2}$ solar systems, respectively. In this study, interest rates/ inflation were not included in the payback time calculation.

\section{Results}

The cumulative solar irradiation on horizontal surface fluctuated from 0.3 to $3.7 \mathrm{kWh} / \mathrm{m}^{2}$ during the experiments while the average measured irradiation was 211 to $776 \mathrm{~W} / \mathrm{m}^{2}$ during the first experiments (nos. 1-3 and nos. 11-13) in August 2017. This fluctuation naturally depended on the weather conditions and the duration of each experiment. The applied average drying airflow rates, controlled by the algorithms, were from 582 to $975 \mathrm{Nm}^{3} / \mathrm{h}$. On sunny days, drying air temperatures in excess of $50{ }^{\circ} \mathrm{C}$ were reached, while on cloudy days, only about $20^{\circ} \mathrm{C}$, i.e., only a few degrees warmer than ambient air, was achieved.

During the second experiment series (nos. 4-10 and nos. 14-22) in 2018 and in Aug 2017 after the adjusted inclination, the cumulative solar irradiation on horizontal surface fluctuated from 1.7 to $6.2 \mathrm{kWh} / \mathrm{m}^{2}$, while the average measured irradiation was 193 to $721 \mathrm{~W} / \mathrm{m}^{2}$. This fluctuation again naturally depended on the weather and the duration of each experiment. In addition, it should be noted that in experiments 15,18 , and 20 , the drying took place day and night. The applied average drying air flow rates, controlled by the algorithms, were from 420 to $811 \mathrm{Nm}^{3} / \mathrm{h}$. On sunny days, drying air temperatures reached nearly $60{ }^{\circ} \mathrm{C}$, while on cloudy days, they were less than $20^{\circ} \mathrm{C}$, only a few degrees warmer than ambient air.

The profitability of all conducted drying experiments is presented in Fig. 4 as a function of measured irradiation on horizontal surface during the tests. The correlation between profitability and cumulated irradiation is almost linear even when the conditions during the experiments varied. The differences between the tested biomass types and batch sizes are more important than the variation in weather conditions during the experiments.

The results in Fig. 4 are derived from varying experimental conditions. The lines show how the benefit from drying depends on the actual solar irradiation and time. They also reveal that drying wood chips made from seasoned wood is more profitable 
Fig. 5 Impact of installed heat recovery on profitability of drying (fresh wood)

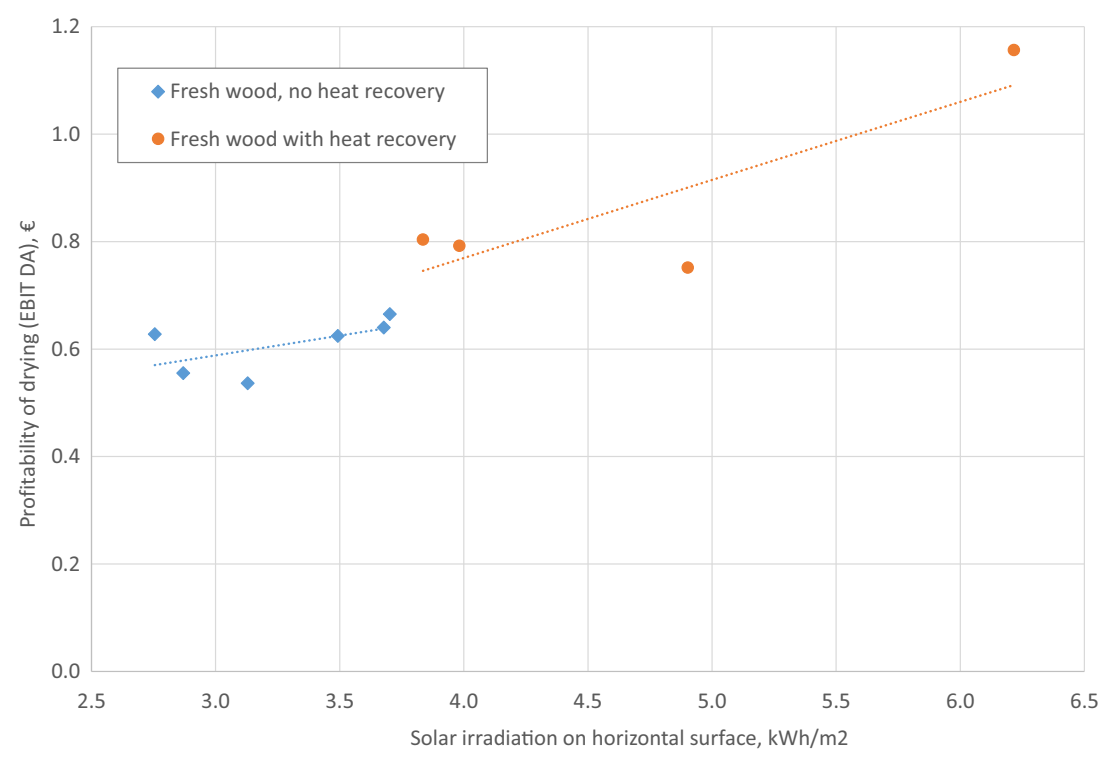

than drying fresh wood chips. The clear difference is due to biomass prices. Both wood chip types were assumed to have the same purchase price before drying ( $€ 21 / \mathrm{MWh})$, which is common for fuelwood in Finland despite the significant moisture difference of the raw materials, however, after drying the price was assumed to be $€ 25 / \mathrm{MWh}$ for all dried wood because of a higher quality of chips. By natural seasoning, it is not possible to reach such a low moisture level. With these assumptions, the value increase compared to the amount of evaporated water is much higher for seasoned wood chips.

The benefit of the heat recovery system, installed in spring 2018, is illustrated in Fig. 5 where the gross margin (EBIT DA) of experiments on fresh wood chips in 2017 and 2018 is compared. Different slopes of the lines indicate better annual profitability when heat recovery is installed.

Because heat recovery improved the profitability of drying significantly, the payback times were evaluated only based on the experiments with heat recovery (excluding the tests without heat recovery). The profitability of the selected experiments is illustrated in Fig. 6 with the equations used in extrapolation for the irradiation of entire drying season.

The profitability of the different dryers was calculated according to the principles described in the previous sections. Extrapolated gross margins were calculated for the test dryer and scaled-up dryers with different drying setups. Actual payback times for the dryers were calculated based on gross margins and investment costs (Table 2).

The calculated payback times are not very appealing to a biomass entrepreneur without subsidies. As previously described, the experiment results show that drying seasoned wood is more profitable than drying fresh wood, particularly if dry matter losses and capital costs of seasoning are not included. The largest system has the shortest payback time due to economy of scale.
Fig. 6 Profitability of drying based on the experiments conducted with heat recovery. The results and trend line equations were later used for annual revenue and payback time calculations

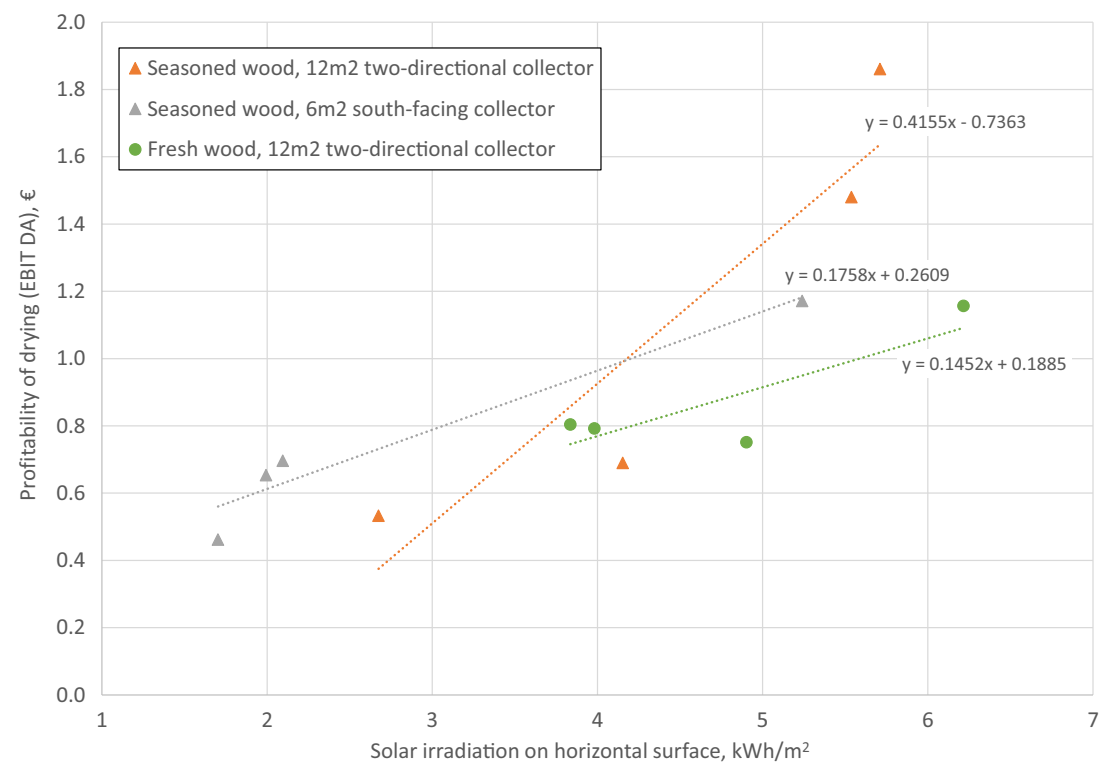


Table 2 Annual profitability and payback times of the test dryer and scaled-up dryers without interest and labor costs (WACC weighted average cost of capital)

\begin{tabular}{|c|c|c|c|c|c|}
\hline & \multicolumn{3}{|c|}{ Gross margin (EBIT DA), $€ /$ year } & \multicolumn{2}{|c|}{$\begin{array}{l}\text { Payback time (WACC 0\%) } \\
\text { years }\end{array}$} \\
\hline & $\begin{array}{l}\text { Test } \\
\text { dryer }\end{array}$ & $\begin{array}{l}90 \mathrm{~m}^{2} \\
\text { system }\end{array}$ & $\begin{array}{l}5000 \mathrm{~m}^{2} \\
\text { system }\end{array}$ & $\begin{array}{l}90 \mathrm{~m}^{2} \\
\text { system }\end{array}$ & $\begin{array}{l}5000 \mathrm{~m}^{2} \\
\text { system }\end{array}$ \\
\hline $\begin{array}{l}\text { Seasoned wood, based on results } \\
\text { with } 6 \mathrm{~m}^{2} \text { system }\end{array}$ & 142 & 2132 & 118,472 & 29 & 20 \\
\hline $\begin{array}{l}\text { Seasoned wood, based on results } \\
\text { with } 12 \mathrm{~m}^{2} \text { system }\end{array}$ & 335 & 2510 & 139,440 & 25 & 17 \\
\hline $\begin{array}{l}\text { Fresh wood, based on } \\
\text { results with } 12 \mathrm{~m}^{2} \text { system }\end{array}$ & 117 & 880 & 48,914 & 71 & 48 \\
\hline
\end{tabular}

In practice, in rural areas, investment subsidies are often available for renewable energy solutions. It is also clear that the drying efficiency can be improved. Moreover, in the best experiment, the calorific value of the wood chips increased by $70 \%$ of the cumulative solar irradiation, while in most experiments, it was only $40 \%$. Furthermore, significantly lower electricity prices are probable in the near future, especially during sunny days when increasing amount of solar power is available in the grid.

Based on the above assumptions, a sensitivity analysis was performed on different dryers and drying materials. It was assumed all options would receive $30 \%$ investment subsidies and that $70 \%$ of the solar irradiation energy received on horizontal surface transfers to wood chips as increased calorific value. Other variables in the analysis were electricity and wood chip prices (Table 3).
Investment subsidies and improved drying efficiency have a marked positive impact on payback times, whereas cheaper electricity shortens them only minimally. This is understandable because operational costs due to power consumption are much smaller compared to fixed costs. Possible effects of fan algorithms were not considered in this analysis. It is likely, however, they would further improve drying profitability. It should also be noted that realistic payback times require a higher price for the dried product compared to raw materials.

\section{Discussion}

In total, 22 drying tests were conducted by VTT's solar-enhanced dryer during 2017 and 2018. During the first experiment series,

Table 3 Payback times of different dryers according to the sensitivity analysis. All options receive $30 \%$ investment subsidy

$$
\begin{aligned}
& 30 \% \text { investment subsidy } \quad \begin{array}{l}
30 \% \text { investment subsidy } \\
\text { and power } € 50 / \mathrm{MWh}
\end{array}
\end{aligned}
$$

Farm dryer with new building and $30 \%$ investment subsidy

\section{Collector surface area of the solar system}

Seasoned wood, based on experiments with $6 \mathrm{~m}^{2}$ system

Seasoned wood, based on experiments with $12 \mathrm{~m}^{2}$ system

Fresh wood, based on experiments with $12 \mathrm{~m}^{2}$ system

Seasoned wood assuming calorific value of wood chips is increased by $70 \%$ of solar energy on horizontal surface

Fresh wood assuming calorific value of wood chips is increased by $70 \%$ of solar energy on horizontal surface

Seasoned wood assuming calorific value of wood chips is increased by $70 \%$ of solar energy on horizontal surface and price of dried chips is $€ 23 / \mathrm{MWh}$

Fresh wood assuming calorific value of wood chips is increased by $70 \%$ of solar energy on horizontal surface and price of dried chips is $€ 23 / \mathrm{MWh}$

Both wood types assuming calorific value of wood chips are increased by $70 \%$ of solar energy on horizontal surface and price of dried chips is $€ 21 / \mathrm{MWh}$

\begin{tabular}{lllcl}
$90 \mathrm{~m}^{2}$ & $5,000 \mathrm{~m}^{2}$ & $90 \mathrm{~m}^{2}$ & $5,000 \mathrm{~m}^{2}$ & $90 \mathrm{~m}^{2}$ \\
21 & 14 & $\begin{array}{l}\text { Cannot be calculated because } \\
\text { the electricity price affects }\end{array}$ & 29 \\
18 & 12 & \multicolumn{2}{c}{ the experiments } & 71 \\
50 & 34 & 9 & 6 & 13 \\
10 & 7 & 17 & 12 & 25 \\
20 & 14 & 16 & 11 & $23^{*}$ \\
18 & 12 & & & $38^{*}$ \\
33 & 22 & 26 & 18 & $80^{*}$ \\
99 & 67 & 56 & 38 &
\end{tabular}

*Electricity price $€ 50 / \mathrm{MWh}$ 
some shortcomings of the used drying setup became apparent. Larger biomass batches could have been dried in the dryer. In addition, the ducting of the system is not optimal because the dryer was originally designed for hot air drying and for simulating different weather conditions. The air ducts are too long for low airflows and temperatures and therefore heat losses in transmission are significant relative to small temperature differences used. In the first series of experiments, the amount of energy used for evaporation compared to solar irradiation energy received on horizontal surface varied from 31 to $42 \%$. Some technical improvements such as a heat recovery unit and better pump controls were installed on the system for the second experiment series. In addition, the position of the collectors was adjusted and collector area was decreased in some experiments. These improvements increased the system efficiency. In one experiment with decreased collector area $(6 \mathrm{~m} 2)$, the calorific value of wood chips was increased by $70 \%$ of irradiation energy received on horizontal surface. Especially with dryer raw material, the impact of higher efficiency would be considerable due to the relatively low moisture content of the wood before drying, which leads to low drying efficiency. This is because if the moisture content of the wood is already below fiber saturation point, usually about $23 \mathrm{w}-\%$, drying becomes slower and more energy consuming when continued below the saturation level [33, 34].

Due to the significant improvements on the drying system between the experiments, economic feasibility was assessed based on the improved system solely. Excluding the results before improvements from economic assessment decreased the amount of data points used in extrapolation. Extrapolation based on only a few points has its weaknesses. However, the results are promising, particularly in the light of better biomass resource efficiency. Therefore, more experiments will be conducted and completely new drying system will be installed at VTT.

Nowadays, it is possible to gain subsidies for many renewable energy systems including solar collectors and PV panels. This would further increase the feasibility of such a drying system. In addition, compared to the calculated efficient utilization hours of the dryer, in practice, the utilization rate might be higher because it is possible to use the dryer even after sunset when there is still heat left in the system and ambient conditions are favorable. Furthermore, on warm evenings such a dryer would still function well as a cold air dryer by utilizing the ambient air temperature.

Possible dry matter losses and storage costs were not included in these calculations as the scope of the study was limited to drying. If the calculations were elaborated to include the costs of dry matter losses, storage, and tied capital, the profitability of drying fresh wood chips would increase. In most of the calculations, higher price (also per MWh) was assumed for dryer biomass. The results are very sensitive to this parameter, as visible in Table 3.

\section{Conclusions}

In Northern Europe, the feasible season for utilizing solar energy for drying lasts about 7 months from March to September. Annual solar irradiation on collectors placed optimally in Central Finland is about $1050 \mathrm{kWh} / \mathrm{m}^{2}$, of which about $90 \%$ is received during those months. With a drying system similar to that used in our drying experiments, it would be possible to dry almost 14 MT of seasoned wood chips to an average moisture of $20 \%$ annually. If the system were scaled up to $90 \mathrm{~m}^{2}$ of collectors, which is feasible for example for farms, it would be possible to dry 104 MT of wood chips, which is usually more than sufficient for annual heating of the farm.

VTT's experiments proved that solar collectors could be effectively applied to biomass drying. The moderate drying temperatures achieved are also ideal for ensuring homogenous drying of wood particles and preventing changes to the physical structure of the biomass or loss of volatiles. The use of low-temperature drying also extends the efficient drying time daily and seasonally. Heat losses are also smaller when low temperatures are applied.

The sensitivity analysis, based on the experiment results, indicates that scaled-up dryers could be utilized in biomass drying with realistic payback times, such as 10-20 years. This seems to require a number of prerequisites. Firstly, natural drying outdoors should be utilized as much as possible before solar-enhanced drying. Secondly, the solar system investment costs are still high, calling for investment subsidies. Thirdly, the system should be run at least as effectively as in our best experiments. Fourthly, it is crucial to add monetary value to dried wood chips compared to wet biomass: our experiments suggest wood chip price should increase by at least $€ 2 / \mathrm{MWh}$ after drying.

In the future, it would be beneficial to study how the energy balance of drying could be improved. One important improvement would be to scale the whole system more carefully. Another interesting approach is to combine a heat pump and solar collectors to enhance convective air drying. This kind of drying setup will be installed at VTT in the fall of 2019. With a heat pump, the drying potential of such a dryer could be increased remarkably.

Acknowledgments The solar-enhanced drying studies were conducted as part of the Sustainable High Value Products from Low Grade Residues and Waste (WasteBusters) and Value-optimized Use of Biomass in a Flexible Energy Infrastructure (VabiSys) projects. The authors wish to acknowledge and thank the Finnish Funding Agency for Innovation (Tekes/Business Finland), our Finnish partner companies and VTT for providing resources for the project.

Funding Information Open access funding provided by Technical Research Centre of Finland (VTT). 


\section{Appendix. Illustrations of the algorithms used} for fan power control

\section{Algorithm 1}

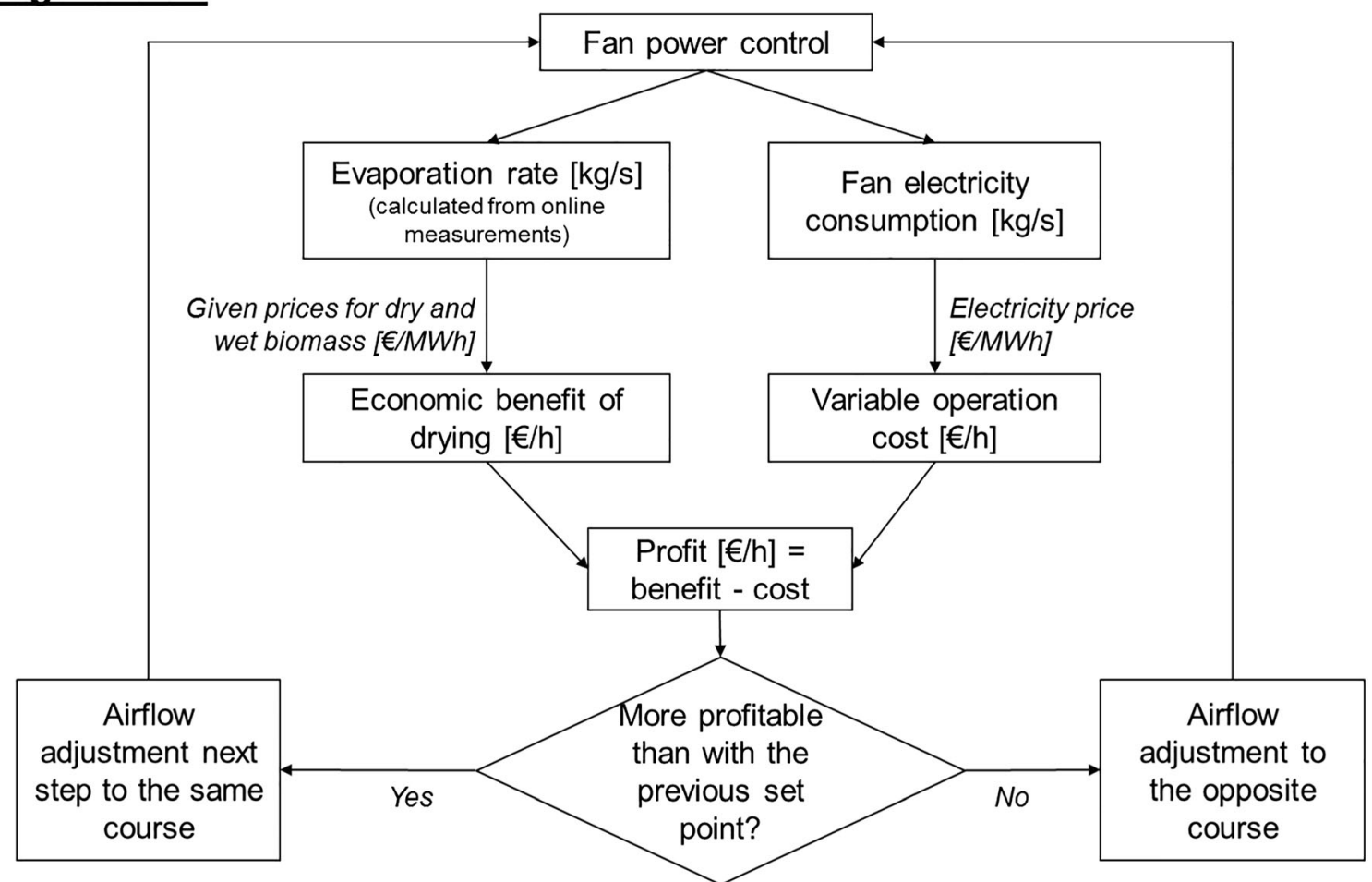

\section{Algorithm 2}

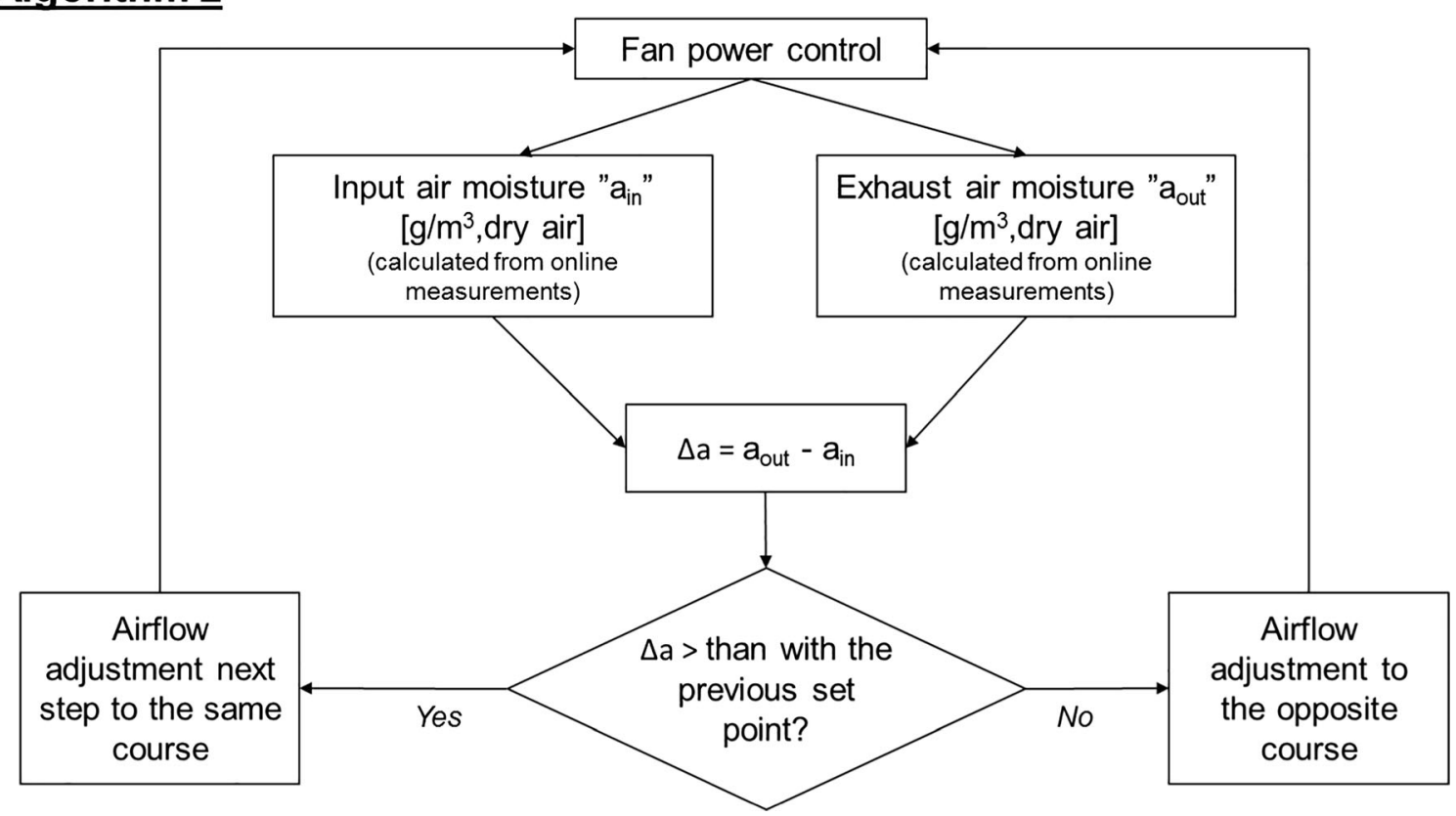




\section{Algorithm 3}

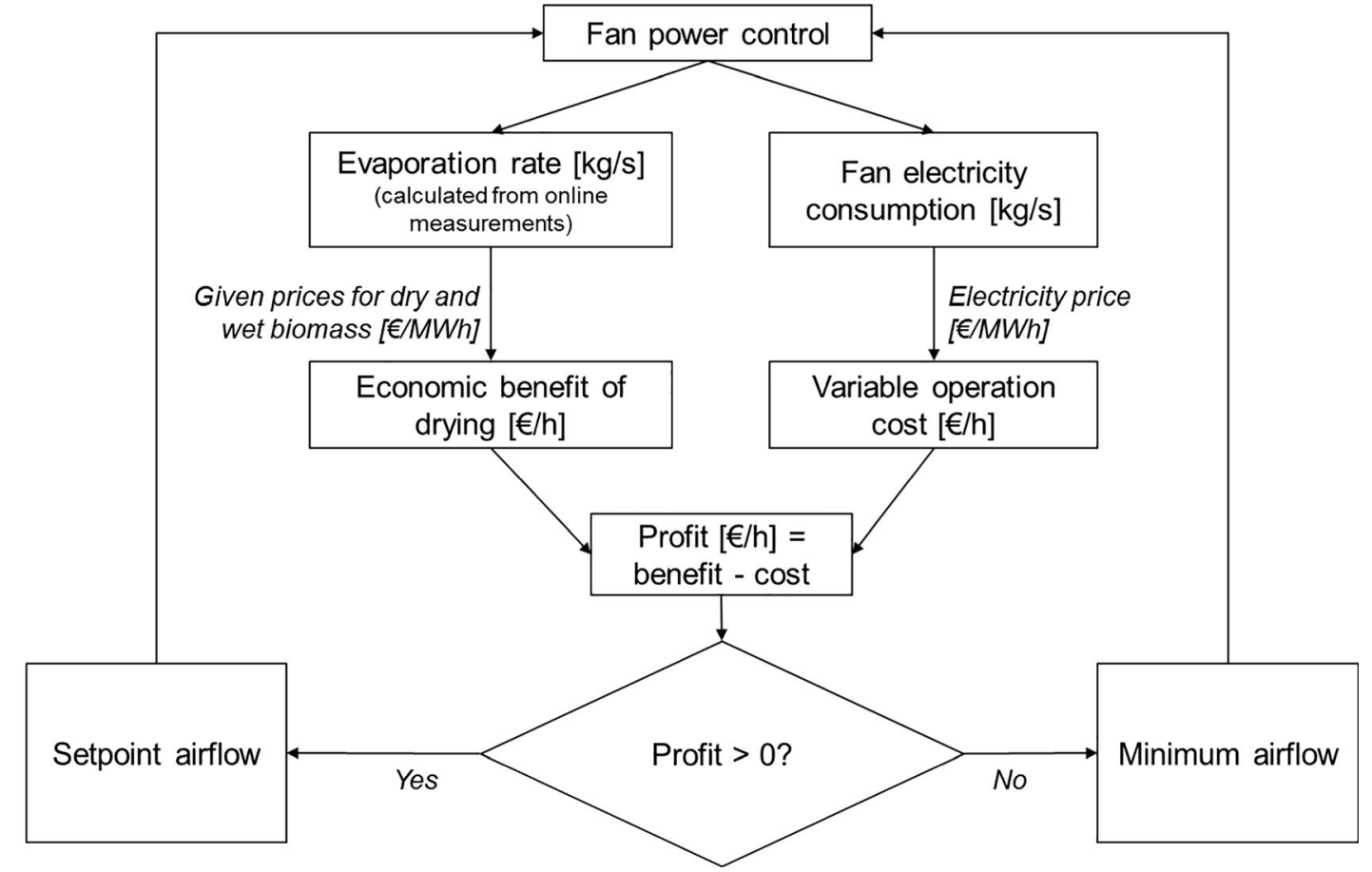

Open Access This article is distributed under the terms of the Creative Commons Attribution 4.0 International License (http:// creativecommons.org/licenses/by/4.0/), which permits unrestricted use, distribution, and reproduction in any medium, provided you give appropriate credit to the original author(s) and the source, provide a link to the Creative Commons license, and indicate if changes were made.

\section{References}

1. Calderón C, Gauthier G \& Jossart J-M (eds.). (2018) Bioenergy Europe, Statistical Report, 2018 Edition.

2. JRC (2014) Carbon accounting of forest bioenergy - Conclusions and recommendations from a critical literature review. European Commission Joint Research Centre, Institute for Energy and Transport. ISBN 978-92-79-25100-9 (pdf). Luxembourg: Publications Office of the European Union, 2014. https://doi.org/10. 2788/29442

3. Kenney K, Smith W, Gresham G, Westover T (2013) Understanding biomass feedstock variability. Biofuels 4(1):111127. https://doi.org/10.4155/bfs. 12.83

4. Pang S, Mujumdar A (2010) Drying of woody biomass for bioenergy: drying technologies and optimization for an integrated bioenergy plant. Dry Technol 28(5):690-701. https://doi.org/10. 1080/07373931003799236

5. Demirbas A (2002) Relationships between heating value and lignin, moisture, ash and extractive contents of biomass fuels. Energy Explor Exploit 20(1):105-111

6. Lewis N (2007) Toward cost-effective solar energy use. Science 09 Feb 2007:Vol. 315. Issue 5813:798-801. https://doi.org/10.1126/ science. 1137014
7. Castillo C, Silva F, Lavalle C (2016) An assessment of the regional potential for solar power generation in EU-28. Energy Policy 88(2016):86-99. https://doi.org/10.1016/j.enpol.2015.10.004

8. Eurostat (2017) Statistics explained. Energy trends. http://ec. europa.eu/eurostat/statistics-explained/index.php/Energy_trends

9. Hakkarainen T, Tsupari E, Hakkarainen E \& Ikäheimo J (2015) The role and opportunities for solar energy in Finland and Europe. Espoo: VTT Technology 217. ISBN-L 2242-1211.

10. Laitila J, Ahtikoski A, Repola J, Routa J (2017) Pre-feasibility study of supply systems based on artificial drying of delimbed stem forest chips. Silva Fennica 51(4):5659. https://doi.org/10.14214/sf. 5659

11. Holmberg H (2007) Biofuel drying as a concept to improve the energy efficiency of an industrial CHP plant. In: Espoo: TKK Dissertations 63. Helsinki University of Technology, Department of Mechanical Engineering, Laboratory of Energy Economics and Power Plant Engineering

12. Routa J, Kolström M, Ruotsalainen J, Sikanen L (2016) Validation of prediction models for estimating the moisture content of logging residues during storage. Biomass Bioenergy. https://doi.org/10. 1016/j.biombioe.2016.08.019

13. Nurmi J (1999) The storage of logging residue for fuel. Biomass Bioenergy 17(1):41-47

14. Virkkunen M, Kari M, Hankalin V, Nummelin J (2015) Solid biomass fuel terminal concepts and a cost analysis of a satellite terminal concept. Espoo: VTT Technology 211 ISSN 2242-122X

15. Routa J, Asikainen A, Björheden R, Laitila J, Röser D (2013) Forest energy procurement: state of the art in Finland and Sweden. WIREs Energy Environ 2013(2):602-613. https://doi.org/10.1002/wene.24

16. Sharma A, Chen C, Vu LN (2009) Renewable and Sustainable Energy Reviews, Volume 13, Issues 6-7. August-September 2009:1185-1210 
17. Andersson G, Asikainen A, Björheden R, Hall P, Hudson J, Jirjis R, Mead J, Nurmi J \& Weetman G (2002) Production of forest energy, in: Richardson J, Björheden R, Hakkila P \& Lowe A, Smith C (Eds.). Bioenergy from sustainable forestry. Guiding principles and practice. Kluwer Academic Publishers, the Netherlands.

18. Routa J, Kolström M, Ruotsalainen J, Sikanen L (2015) Precision Measurement of Forest Harvesting Residue Moisture Change and Dry Matter Losses by Constant Weight Monitoring. Int J For Eng. https://doi.org/10.1080/14942119.2015.1012900

19. Krigstin S, Wetzel S (2016) A review of mechanisms responsible for changes to stored biomass fuels. Fuel 175(2016):75-86

20. Zabel R \& Morrel J. 1992. Wood microbiology: decay and its prevention. Academic Press:1992.

21. Sikanen L \& Kinnunen J-P. 2016. Fast-track approach. In: Energy Biomass Supply Chain Concepts Including Terminals. Luonnonvarakeskus (Luke) (2016), 67-69.

22. Laitila J, Ahtikoski A, Repola J \& Routa J (2017) Pre-feasibility study of supply systems based on artificial drying of delimbed stem forest chips. https://doi.org/10.14214/sf.5659.

23. JRC (2017) Photovoltaic Geographical Information System Interactive Maps. http://re.jrc.ec.europa.eu/pvgis/apps4/pvest.php\#

24. Fudholi A, Sopian K, Ruslan MH, AlGoul MA, Sulaiman MY (2010) Review of solar dryers for agricultural and marine products. Renew Sust Energ Rev 14(2010):1-30

25. El-Sebaii AA, Shalaby SM (2012) Solar drying of agricultural products: a review. Renew Sust Energ Rev 16(2012):37-43
26. VijayaVenkataRaman S, Iniyan S, Goic R (2012) A review of solar drying technologies. Renew Sust Energ Rev 16(2012):2652-2670

27. Fudholi A, Kamaruzzaman S, Bakhtyar B, Gabbasa M, Othman M \& Ruslan M (2015) https://doi.org/10.1016/j.rser.2015.07.026.

28. Sharma A, Chen C, Lan NV (2009) Solar-energy drying systems: a review. https://doi.org/10.1016/j.rser.2008.08.015

29. Raitila J, Tsupari E (2018) Solar enhanced drying improving the woody biomass supply chain. 26th European Biomass Conference and Exhibition, 14-17 May, 2018 Copenhagen. Proceedings: 51-54. https://doi.org/10.5071/26thEUBCE2018-1AO.7.3.

30. EN ISO 17225-1:2014. Solid biofuels - fuel specifications and classes - part 1: general requirements.

31. Statistics Finland (2019) Fuel prices in electricity production. https://www.stat.fi/til/ehi/2019/01/ehi_2019_01_2019-06-12_tie_ 001 en.html

32. Keski-Mattinen V (2018) Construction illustrations and cost estimates of biomass dryers provided by Pro Agria Central Finland.

33. Hukka A (1996) A mathematical model for simulation of softwood drying in temperatures above boiling point of water with special attention to the boundary conditions. Drying Technology J, Vol 14, No 7.

34. Hunter AJ (1993) On movement of water through wood - The diffusion coefficient. Wood Sci Technol 27:401-408

Publisher's Note Springer Nature remains neutral with regard to jurisdictional claims in published maps and institutional affiliations. 